ISSN(print): 2644-0490, ISSN(online): 2644-0504

Volume 4 Issue 03 March 2021

Article DOI: 10.47191/jefms/v4-i3-06, Impact Factor: 6.228

Page No.- 149-155

\title{
Internationalization and Firm Performance - Case of Manufacturing Firms in Argentina
}

\author{
Phan Anh Tu \\ College of Economics, Can Tho University, Campus II, Can Tho City, Vietnam
}

\begin{abstract}
The main objective of the study is to investigate the relationship between the degree of internationalization and the performance of businesses in the manufacturing sector in Argentina. Using a panel data collected by the World Bank over the years 2006, 2010, and 2017 of the manufacturing firms in Argentina, the regression results show empirical evidence of a nonlinear relationship (an inverted-U shape) between the degree of internationalization and firm performance of manufacturing firms in Argentina. The implication of this study provides the strategic thinking for managers to understand and come up with the right strategies to reduce risks and enrich business performance in the process of internationalization.
\end{abstract}

KEYWORDS: Internationalization, performance, manufacturing, inverted U-shape, Argentina

\section{INTRODUCTION}

Argentina is an upper-middle income country (Pratt, 1990), the third largest economy in Latin America (after Brazil and Mexico) with a growth rate of 2,819\% in 2017 (World Bank, 2021). Internationalization (export and export expansion) is the economic driving force with outstanding products such as soybeans, energy and fuel, means of transport ... This is the founding country of many national organizations. The United Nations, Mercosur, Union of South American Nations, OEI, World Bank Group, World Trade Organization, a member of the G-20 Large Economies Group and Allied Bloc not part of the US NATO.

Internationalization is not only a matter of concern in Argentina, but it is also a topic that attracts researchers from all over the world. There are many empirical studies showing that internationalization has a linear relationship to firm business performance (Daniels \& Bracker, 1989; Schwens et al., 2018). There are also many studies that suggest that there is a non-linear relationship between internationalization and firm business performance (Fernández \& Díez, 2015; Gomes \& Ramaswamy, 1999).

Although there have been many experimental studies examining this relationship, the results are mixed and there is no consensus. More importantly, this relationship can vary depending on the specific context of each country and depending on the area of activity of the business. Manufacturing is Argentina's main economic sector. In 2017, this sector created 12,835\% of the added value in the structure of the national GDP (World Bank, 2021). Therefore, researching and clarifying the relationship of internationalization and business performance of enterprises in the manufacturing sector is necessary.

In summary, this study investigates the relationship between the degree of internationalization (DOI) and firm performance in Argentina. Our research will contribute to the literature review contemporary of internationalization by threefold: (1) provide additional empirical evidence for the theory of internationalization; (2) highlight with a vital role of the non-linear relationship between the DOI and firm performance; (3) provide a particular research context, i.e., manufacturing firms in the fastest-growing economies.

\section{THEORETICAL BACKGROUND AND RESEARCH METHODOLOGY \\ 2.1 Theoretical background}

One of the best known and theoretical prophecies about internationalization is the "Internationalization process" theory, or "Model Uppsala", studied by Johanson and Vahlne (1977). Based on a research-based model of Swedish multinationals, they suggested that internationalization is a fragmented process. Specifically, in the early stages of business firms operates only at the current market. In the second stage, firms begin to focus on expanding cross-border business by exporting to close markets 


\section{Internationalization and Firm Performance - Case of Manufacturing Firms in Argentina}

through agents. In the next stage, due to binding with needed resources in the international market, firms often set up their branches abroad and at the end of the period, firms proceed to build up production facilities in foreign markets. Therefore, business performance will also change from time to time.

According to Johanson \& Vahlne (1977), in the early stage of internationalization, manufacturing firms in Argentina mainly carry out internationalization in countries that are geographically close, as well as low-level gap of development such as Chile, Uruguay and Brazil. This makes it easy for firms to penetrate and absorb international market knowledge easily. With a moderate degree of internationalization, firms can take advantage of the benefits of learning from international experiences to come up with strategies that suit the conditions and circumstances of each business, absorbing the new technology and innovative ideas to improve product quality. In addition, firms also have access to a variety of efficient alternative resources, reduce fixed costs, and use input resources more efficiently (Wang et al., 2011). Internationalization also gives firms the opportunity to expand sales and prolong the life cycle of products (Daniels \& Bracker, 1989). Moreover, the expansion of internationalization helps them to gain economies of scale, and thereby bringing business efficiency to their businesses (Wang et al., 2011).

However, firms would increase the level of internationalization require a very complex governance and coordination strategy (Gomes \& Ramaswamy, 1999). If not flexible to adjust a suitable management system, it will affect the firm performance. Moreover, when expanding the market, firms have to face the differences in culture and customer behaviors. This costs firms to learn while this amount of market knowledge is difficult to absorb successfully (Bowman \& Helfat, 2001). Raising the intensive degree of internationalization to regions with large development gaps also makes it difficult to transfer corporate resources (Wang et al., 2011). Resources are not transferred in time, making firms lose their competitive advantage in the international arena, negatively affecting the business performance.

From the above arguments, the study hypothesizes as follows:

Hypothesis H1: There is an inverse U-shaped non-linear relationship between DOI and firm performance of manufacturing firms in Argentina.

\subsection{Methodology}

The data used in the study were in the World Bank Enterprise Surveys project with 2,297 manufacturing and service firms in Argentina during 2006, 2010, and 2017. Participants are managers of the firms. This study only studies the relationship between internationalization and business performance of firms in the manufacturing sector, so the data included in the analysis is cross-sectional data with 189 firms. The study uses statistical methods to describe the research objects with the statistical quantities used such as average value, maximum value, minimum value, standard deviation. In this study, Pearson's bivariate correlation coefficients were used to check the multicollinearity phenomenon between the independent variables before regression was performed. Besides, the study uses the Ordinary Least Square Method (OLS) to estimate the impact of the independent variables on the dependent variable.

Estimated model is given by:

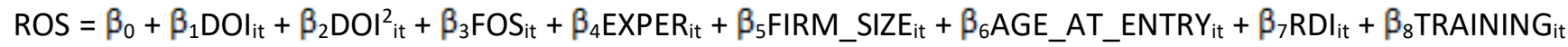
$+\beta_{11}$ FINANCE $_{i t}+\beta_{12}$ LAND $_{i t}+\mu_{i t}$

Dependent variable: ROS (business performance of the firm) is measured by the ratio of profit to total revenue (Contractor et al., 2003).

Independent variable: DOI (degree of internationalization) is measured by the ratio of foreign sales to total sales (Sullivan, 1994b). $\mathrm{DOI}^{2}$ is a squared DOI.

$\beta 0$ : is the intercept of the model (the value of ROS when all independent variables are 0);

$\beta 1$ - $\beta 11$ : respectively the estimated coefficients of the independent variables and control variables in the model;

$\mathrm{i}$ : Enterprises interviewed; t: time of survey (2006, 2010, and 2017);

$\mu$ it: Error of the ith object at the time

Control variable

FOS (firm ownership structure): measured by dummy variable, taking value equal to 1 if the firm has a percentage of state ownership and 0 if not available (Reuer et al., 2016). When firms are state-owned, there can be more capital subsidies and easier access to resources for firms. Therefore, the study expects that the ownership structure of the business has a positive impact on the firm performance.

EXPER (managerial experience): measured by the number of years of experience in management as of 2006, 2010 and 2017 (Contractor et al., 2003). The more experienced managers are those who accumulate useful market knowledge, help 


\section{Internationalization and Firm Performance - Case of Manufacturing Firms in Argentina}

businesses come up with the right strategies, help businesses limit risks in the volatile market, as well as help improve business performance. Therefore, managerial experience is expected to have a positive impact on the performance of the business.

FIRM_SIZE (firm size): measured by the natural base logarithm of the total number of employees (Reuber \& Fischer, 1997). The larger the scale of the enterprise, the more costly coordination and operation it cost, the more complex the governance apparatus, leading to bureaucracy and difficulty in decision making. Therefore, firm size is expected to have a negative impact on firm performance.

AGE_AT_ENTRY (years of operation up to date of accession): measured by the year the firm had first international sales minus the year it was founded (Brush, 1992). Aging firms entering large industries often have a lot of experience to overcome obstacles easily. At the same time, these businesses also build reputations and extensive relationships. Therefore, businesses have access to resources and thereby improving business performance. Therefore, the study expects the number of years of operation to the time of accession to have a positive impact on the business performance of the enterprise.

RDI (research and development intensity): measured as total R\&D expenditure on total revenue (Kotabe et al., 2002). The greater the intensity of $R \& D$, the more it helps businesses catch up with market trends, create competitiveness and enhance business performance. Therefore, the study expects research and development intensity to have a positive impact on the business performance of enterprises.

TRAINING (labor training): measured by a dummy variable, takes 1 if the firm has formal training programs for employees, 0 if otherwise (Héctor Alberto Botello, 2014). Training programs helps improve the qualifications of the staff of enterprises. From there, helping employees to have enough capacity to develop, create, and at the same time be able to easily access and operate advanced technology equipment and lines. Therefore, it is possible to increase efficiency and improve business performance. Labor training is expected to have a positive impact on the firm performance.

FINANCE (access to finance): is measured by how managers of enterprises respond to questions on the Likert-5 scale: "To what extent, access to finance is a hindrance to the performance of enterprise?" (0: No obstacles --> 4: Extremely obstacles). When access to finance is increasingly hindered, it will limit scaling and market expansion, and limit investment in research and development, which can affect the sustainable operation of businesses. Therefore, access to finance is expected to have a negative impact on the firm performance.

LAND (access to land): similar to access to finance, this variable is measured by how managers of the firm respond to questions on the Likert-5 scale: "To what extent, to approach Is land a hindrance to business operations? " (0: No obstacles --> 4: Extremely obstacles). When the barriers to access to land are larger, firms will find it more difficult to expand their operation scale, causing difficulties for their operations if they cannot choose a favorable location, increasing their operating costs and businesses such as rental, purchase, informal fees and information and transaction costs. At the same time, it can also delay business operations. Therefore, this variable is expected to have a negative impact on the business performance of the business.

\section{RESULTS AND DISCUSSIONS}

The descriptive statistical results of the variables in the model are shown in Table 2 . Thereby, the average rate of return on revenue of the enterprise is $24,346 \%$, the maximum value is $83,918 \%$ and the smallest value is $-74 \%$. On average, the level of internationalization of the business is $26,767 \%$ with the maximum value of $100 \%$ and the minimum value of $0 \%$, there are enterprises that fully internationalize. The correlation matrix of variable pairs in Table 3 shows that the variance magnification coefficients of the variables are all less than 10 and the correlation coefficients are less than 0.800 , so there is no multicollinearity phenomenon occurring in the model. The estimation results are presented in Table 4 with four models from the Hierachical Model, which are respectively put into the control variable group model and the independent variable DOI with increasing powers of DOI in order to consider the non-linear relationship of the degree of internationalization to the firm's business performance. All models are statistically significant with very small absolute value of Log likelihood (Prob>chi2 $=0.00)$. The explanation of the relationship between the variables in the model will focus on model 4 because the independent variables are statistically significant. The coefficient $\mathrm{R}^{2}$ in this model is $21,300 \%$, showing that the dependent variable explained by the independent variables is quite high.

Table 1. Descriptive statistics

\begin{tabular}{|c|c|c|c|c|c|c|c|}
\hline & Variables & Obs. & VIF & Mean & S.D & Min & Max \\
\hline $\begin{array}{l}\text { Depedent } \\
\text { variable }\end{array}$ & Return on sales (ROS) & 189 & & 24.346 & 22.684 & -74 & 83.918 \\
\hline Independent & Degree of internationalization (DOI) & 189 & 1.080 & 26.767 & 26.940 & 1 & 100 \\
\hline
\end{tabular}




\begin{tabular}{|c|c|c|c|c|c|c|c|}
\hline \multicolumn{8}{|l|}{ variable } \\
\hline \multirow[t]{8}{*}{ Control variable } & Firm Ownership structure (FOS) & 189 & 1.080 & 0.005 & 0.073 & 0 & 1 \\
\hline & Managerial experience (EXPER) & 189 & 1.080 & 27.571 & 12.081 & 1 & 60 \\
\hline & Firm size (FIRM_SIZE) & 189 & 1.350 & 4.279 & 1.431 & 1.386 & 8.455 \\
\hline & Firm age at entry (AGE_AT_ENTRY) & 189 & 1.170 & 18.116 & 20.581 & 0 & 105 \\
\hline & Research \& Development Intense (RDI) & 189 & 1.080 & 2.394 & 3.423 & 0.013 & 24 \\
\hline & Labor training (TRAINING) & 189 & 1.120 & 0.804 & 0.398 & 0 & 1 \\
\hline & Access to land (LAND) & 189 & 1.150 & 1.175 & 1.390 & 0 & 4 \\
\hline & Access to finance (FINANCE) & 189 & 1.130 & 2.021 & 1.198 & 0 & 4 \\
\hline
\end{tabular}

Source: World Bank Enterprises Surveys (2020)

Table 2. Bivariate Correlation

\begin{tabular}{|c|c|c|c|c|c|c|c|c|c|c|c|c|c|c|c|c|c|c|}
\hline Variable & Mean & S.D & (1) & & (2) & & (3) & & (4) & & (5) & & (6) & (7) & (8) & (9) & & (10) \\
\hline \multirow[t]{2}{*}{ (1) ROS } & 24.346 & 22.6 & 1.0 & & & & & & & & & & & & & & & \\
\hline & & 84 & 00 & & & & & & & & & & & & & & & \\
\hline \multirow[t]{3}{*}{ (2) DOI } & 26.767 & 26.9 & - & & 1.0 & & & & & & & & & & & & & \\
\hline & & 40 & 0.0 & & 00 & & & & & & & & & & & & & \\
\hline & & & 56 & & & & & & & & & & & & & & & \\
\hline \multirow[t]{3}{*}{ (3) FOS } & 0.005 & 0.07 & 0.0 & & - & & 1.0 & & & & & & & & & & & \\
\hline & & 3 & 93 & & 0.0 & & 00 & & & & & & & & & & & \\
\hline & & & & & 24 & & & & & & & & & & & & & \\
\hline \multirow[t]{3}{*}{ (4) EXPER } & 27.571 & 12.0 & - & & - & & 0.0 & & 1.0 & & & & & & & & & \\
\hline & & 81 & 0.0 & & 0.0 & & 13 & & 00 & & & & & & & & & \\
\hline & & & 59 & & 82 & & & & & & & & & & & & & \\
\hline (5) & 4.279 & 1.43 & 0.0 & & - & & 0.1 & $* *$ & - & $*$ & 1.0 & & & & & & & \\
\hline FIRM_SIZ & & 1 & 12 & & 0.0 & & 99 & $*$ & 0.1 & $*$ & 00 & & & & & & & \\
\hline E & & & & & 65 & & & & 63 & & & & & & & & & \\
\hline (6) & 18.116 & 20.5 & 0.1 & $*$ & - & $*$ & - & & 0.0 & & 0.2 & $* *$ & 1,0 & & & & & \\
\hline AGE_AT_ & & 81 & 74 & $*$ & 0.1 & $*$ & 0.0 & & 98 & & 45 & $*$ & 00 & & & & & \\
\hline ENTRY & & & & & 85 & & 64 & & & & & & & & & & & \\
\hline \multirow[t]{3}{*}{ (7) RDI } & 2.394 & 3.42 & - & & - & & - & & 0.0 & & - & $* *$ & - & 1.0 & & & & \\
\hline & & 3 & 0.0 & & 0.0 & & 0.0 & & 92 & & 0.1 & $*$ & 0.0 & 00 & & & & \\
\hline & & & 95 & & 61 & & 51 & & & & 93 & & 37 & & & & & \\
\hline (8) & 0.804 & 0.39 & 0.0 & & 0.1 & $*$ & 0.0 & & - & $*$ & 0.2 & $* *$ & 0.0 & - & 1.0 & & & \\
\hline TRAININ & & 8 & 42 & & 38 & & 36 & & 0.1 & & 70 & $*$ & 29 & 0.1 & 00 & & & \\
\hline G & & & & & & & & & 22 & & & & & 21 & & & & \\
\hline \multirow[t]{3}{*}{ (9) LAND } & 1.175 & 1.39 & - & $*$ & - & & - & & - & & - & & 0.1 & 0.1 & 0.0 & 1.0 & & \\
\hline & & 0 & 0.1 & & 0.0 & & 0.0 & & 0.0 & & 0.1 & & 34 & 58 & 04 & 00 & & \\
\hline & & & 23 & & 77 & & 09 & & 49 & & 05 & & & & & & & \\
\hline (10) & 2.021 & 1.19 & - & $*$ & 0.0 & & 0.0 & & 0.0 & & - & $* *$ & - & 0.0 & - & 0.2 & $* *$ & 1.0 \\
\hline \multirow[t]{2}{*}{ FINANCE } & & 8 & 0.1 & & 25 & & 60 & & 08 & & 0.2 & $*$ & 0.0 & 49 & 0.0 & 66 & $*$ & 00 \\
\hline & & & 40 & & & & & & & & 06 & & 33 & & 81 & & & \\
\hline
\end{tabular}

Note: * significant at $10 \%$ level, ** significant level at 5\%, *** significant level $1 \%$.

Table 3. OLS Regression results

\begin{tabular}{|c|c|c|c|c|c|c|c|c|}
\hline & Model 1 & & Model 2 & & Model 3 & & Model 4 & \\
\hline Constant & $\begin{array}{l}50.434 \\
(8.708)\end{array}$ & $\begin{array}{l}* * \\
*\end{array}$ & $\begin{array}{l}48.080 \\
(8.634)\end{array}$ & $* * *$ & $\begin{array}{l}52.894 \\
(9.106)\end{array}$ & $* * *$ & $\begin{array}{l}54.587 \\
(9.513)\end{array}$ & $* * *$ \\
\hline \multicolumn{9}{|l|}{ Independent } \\
\hline Degree of Internationalization (DOI) & $\begin{array}{l}-0.099 \\
(0.061)\end{array}$ & & $\begin{array}{l}0.366 \\
(0.196)\end{array}$ & $*$ & $\begin{array}{l}-0.304 \\
(0.461)\end{array}$ & & $\begin{array}{l}-0.776 \\
(0.884)\end{array}$ & \\
\hline Degree of Internationalization (DOI2) & & & $\begin{array}{l}-0.005 \\
(0.002)\end{array}$ & $* *$ & $\begin{array}{l}0.015 \\
(0.013)\end{array}$ & & $\begin{array}{l}0.039 \\
(0.041)\end{array}$ & \\
\hline
\end{tabular}


Internationalization and Firm Performance - Case of Manufacturing Firms in Argentina

\begin{tabular}{|c|c|c|c|c|c|c|c|c|}
\hline Degree of Internationalization (DOI3 ) & & & & & $\begin{array}{l}-0.000 \\
(0.000)\end{array}$ & & $\begin{array}{l}-0.001 \\
(0.001)\end{array}$ & \\
\hline Degree of Internationalization (DOI4 ) & & & & & & & $\begin{array}{l}0.000 \\
(0.000)\end{array}$ & \\
\hline \multicolumn{9}{|l|}{ Control } \\
\hline Firm ownership structure (FOS) & $\begin{array}{l}44.602 \\
(21.957)\end{array}$ & $* *$ & $\begin{array}{l}44.053 \\
(21.640 \\
)\end{array}$ & $* *$ & $\begin{array}{l}47.439 \\
(21.648)\end{array}$ & $* *$ & $\begin{array}{l}48.153 \\
(21.71 \\
6)\end{array}$ & $* *$ \\
\hline Managerial experience (EXPER) & $\begin{array}{l}-0.152 \\
(0.135)\end{array}$ & & $\begin{array}{l}-0.176 \\
(0.134)\end{array}$ & & $\begin{array}{l}-0.180 \\
(0.133)\end{array}$ & & $\begin{array}{l}-0.180 \\
(0.133)\end{array}$ & \\
\hline Firm size (FIRM_SIZE) & $\begin{array}{l}-2.043 \\
(1.255)\end{array}$ & & $\begin{array}{l}-2.209 \\
(1.239)\end{array}$ & $*$ & $\begin{array}{l}-2.496 \\
(1.247)\end{array}$ & $* *$ & $\begin{array}{l}-2.468 \\
(1.250)\end{array}$ & $*$ \\
\hline Firm age at entry (AGE_AT_ENTRY) & $\begin{array}{l}0.219 \\
(0.082)\end{array}$ & $\begin{array}{l}* * \\
*\end{array}$ & $\begin{array}{l}0.222 \\
(0.080)\end{array}$ & $* * *$ & $\begin{array}{l}0.217 \\
(0.080)\end{array}$ & $* * *$ & $\begin{array}{l}0.211 \\
(0.081)\end{array}$ & $* * *$ \\
\hline Research \& Development Intense (RDI) & $\begin{array}{l}-0.500 \\
(0.467)\end{array}$ & & $\begin{array}{c}-0.553 \\
(0.460)\end{array}$ & & $\begin{array}{l}-0.534 \\
(0.458)\end{array}$ & & $\begin{array}{l}-0.516 \\
(0.460)\end{array}$ & \\
\hline Labor training (TRAINING) & $\begin{array}{l}4.746 \\
(4.146)\end{array}$ & & $\begin{array}{l}4.030 \\
(4.096)\end{array}$ & & $\begin{array}{l}4.757 \\
(4.103)\end{array}$ & & $\begin{array}{l}5.076 \\
(4.141)\end{array}$ & \\
\hline Access to land (LAND) & $\begin{array}{l}-1.770 \\
(1.195)\end{array}$ & & $\begin{array}{l}-1.919 \\
(1.180)\end{array}$ & & $\begin{array}{l}-1.997 \\
(1.175)\end{array}$ & $*$ & $\begin{array}{l}-1.968 \\
(1.178)\end{array}$ & $*$ \\
\hline Access to finance (FINANCE) & $\begin{array}{l}-2.323 \\
(1.368)\end{array}$ & $*$ & $\begin{array}{l}-2.610 \\
(1.353)\end{array}$ & $*$ & $\begin{array}{l}-2.712 \\
(1.349)\end{array}$ & $* *$ & $\begin{array}{l}-2.837 \\
(1.366)\end{array}$ & $* *$ \\
\hline Year 2010 & $\begin{array}{l}-14.781 \\
(3.563)\end{array}$ & $\begin{array}{l}* * \\
*\end{array}$ & $\begin{array}{l}-14.774 \\
(3.511)\end{array}$ & $* * *$ & $\begin{array}{l}-14.398 \\
(3.504)\end{array}$ & $* * *$ & $\begin{array}{l}- \\
14.247 \\
(3.518)\end{array}$ & $* * *$ \\
\hline Year 2017 & $\begin{array}{l}-15.699 \\
(6.891)\end{array}$ & $* *$ & $\begin{array}{l}-13.159 \\
(6.867)\end{array}$ & $* *$ & $\begin{array}{l}-13.540 \\
(6.841)\end{array}$ & $* *$ & $\begin{array}{l}- \\
13.353 \\
(6.859)\end{array}$ & $* *$ \\
\hline $\mathrm{N}$ & 189 & & 189 & & 189 & & 189 & \\
\hline $\mathrm{R} 2$ & 0.185 & & 0.213 & & 0.225 & & 0.226 & \\
\hline Prob $>\mathrm{F}$ & 0.000 & & 0.000 & & 0.000 & & 0.000 & \\
\hline
\end{tabular}

According to model 2 (Table 4) shows that research hypothesis $H 1$ is supported $(\beta 1=0.366 ; p<0.100$ and $\beta 2=-0.005 ; p$ $<0.050)$. This confirms an inverse $U$-shaped non-linear relationship between the degree of internationalization and the business performance of the manufacturing firms in Argentina. This result is similar to other studies of Chiao \& Yang (2011), Fernández \& Díez (2015), Tu et al. (2021).

Taking the first derivative of the return on revenue (ROS) function by the degree of internationalization (DOI), we have:

$$
\begin{aligned}
& \frac{\partial \mathrm{ROS}}{\partial \mathrm{DOl}}=0.366-0.005 \times 2 \times \mathrm{DOI} \\
& \begin{aligned}
\frac{\partial \mathrm{ROS}}{\partial \mathrm{DOl}}=0 & \Rightarrow \mathrm{DOI}=36.600(\%) \\
& \Rightarrow \mathrm{ROS}=28.459(\%)
\end{aligned}
\end{aligned}
$$

This means that in the first phase of international expansion, the global strategy's benefits will outweigh the costs, so the $P$ of the business will be remarkably enhanced. These benefits will be significant and essential for firms, especially in the fastgrowing economy when they operate in a limited and competitive domestic market and widen openness policy. Specifically, in phase 1, companies often start to expand their operations in countries in the region close to and have many similarities with their home markets. This helps the companies to minimize the costs associated with adapting to the new institutional and cultural environment. However, in the second phase, as companies increase their penetration into foreign markets, foreign responsibilities or so-called 'liability of foreignness', or 'liability of outsidership' (costs related to being outside a robust business network of relationships and contacts in a new market) will arise as the geographical and cultural gap between origin countries and host countries causes the rise in costs such as transaction costs, managerial costs as well as inadequate learning and lack of experience (Tu et al., 2021). The benefits of internationalization tend to decrease after a certain point of time (or after an 


\section{Internationalization and Firm Performance - Case of Manufacturing Firms in Argentina}

inflection point at $\mathrm{DOI}=36.6 \%$ ) because internationalization costs increase faster than benefits, leading to a decrease in profits. The two-stage relationship is proven by Ruigrok \& Wagner (2003).

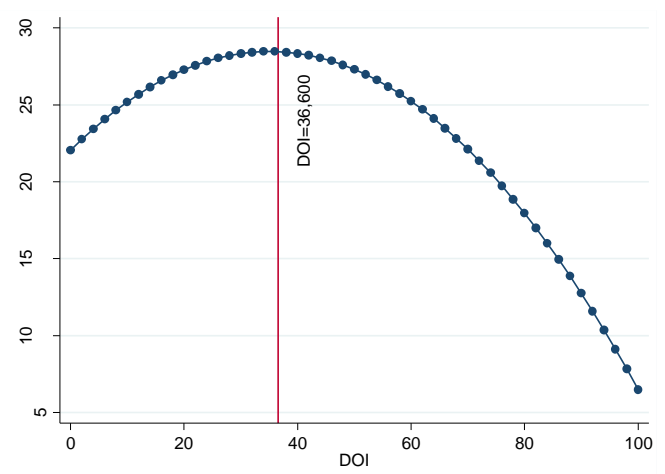

Figure 1. Relationship between DOI and firm performance of manufacturing firms in Argentina

Firm ownership structure has a positive impact on business performance $(\beta=44,053, p<0.050)$. Firm size has a negative impact on the business performance of the firm $(\beta=-2,209, p<0.100)$ while the number of years of operation up to the time of joining has a positive relationship with performance $(\beta=0.217, p<0.010)$. Conversely, firms' access to finance have a negative impact on the firm performance $(\beta=-2,610, p<0.100)$. In addition, when comparing the business performance of enterprises through 2010 and 2017, the business performance of the enterprises decreased, specifically in 2010 the business activities of enterprises in the manufacturing sector decreased by 14,774\% compared to 2006 ( $\beta=-14,774, p<0.010)$. Compared with 2016, the business performance of enterprises decreased by $13,159 \%(\beta=-13,159, p<0.050)$. This is due to the political instability in Argentina for a long time, and at the same time corruption is taking place seriously affecting business operations. In 2017, Argentina had $39 / 100$ points, ranking 85 out of 180 countries according to Transparency International (Transparency International, 2017). In addition, despite many efforts, Argentina's infrastructure is still inadequate, unable to meet the increasing demand for travel and transportation.

\section{CONCLUSION}

The research results show that the DOI and firm performance of manufacturing firms in Argentina is an inverted U-shaped nonlinear relationship. In addition, research also shows that the ownership structure of a business and the number of years to the time of entry have a positive impact on the business performance. However, firm size and access to finance have negative effects on firm's business performance. This study provides the following implications. First, firms need to focus on building an appropriate internationalization strategy in each period. Specifically, in the first stage, enterprises need to thoroughly understand the target market, then consider the appropriate method of market entry, promote competitive advantages to improve business efficiency. In the process, firms should invest in research and development and hence accumulate international knowledge as well as develop new resources. Firms may foresee the risks of expanding internationalization to bring out the right business activities to reduce operating costs and develop sustainably in the process of deep internationalization. Second, policy makers need to provide policies to support businesses in the process of internationalization such as capital support, information about investment programs, and minimizing complicated procedures in accessing resources, issuing policies to support technology transfer, training workers in time, strengthening infrastructure construction. Therefore, firms can maintain operations and long-term development in the international arena.

There are still some limitations to this study. First, using an index to measure business performance (ROS) and DOI is likely not to generalize its results. Therefore, future research needs to expand to measure other business performance indicators such as ROE, ROA, or internationalization by the number of branches operating in different countries, thereby increasing the estimated results' generalization. Besides, business diversification in various sectors such as service is also a need to be examined for future research. Finally, the mediating factors such as culture, geography and institution may need to be taken into consideration.

\section{REFERENCES}

1) Bowman, E. H. and Helfat, C. E. 2001. Does corporate strategy matter? Strategic Management Journal, 22(1), 1-23.

2) Brush, J. E., Faxon, D. P., Salmon, S., Jacobs, A. K., and Ryan, T. J. 1992. Abnormal endothelium-dependent coronary vasomotor in hypertensive patients. Journal of the American College of Cardiology, 19(4), 809-815. 


\section{Internationalization and Firm Performance - Case of Manufacturing Firms in Argentina}

3) Contractor, F. J., Kundu, S. K., and Hsu, C. C. 2003. A three-stage theory of international expansion: The link between multinationality and performance in the service sector. Journal of international business studies, 34(1), 5-18.

4) Chiao, Y. C. and Yang, K. P. 2011. Internationalization, intangible assets and Taiwanese SMEs' performance: Evidence of an Asian newly-industrialized economy. African Journal of Business Management, 5(3): 641-655.

5) Daniels, J. D., and Bracker, J. 1989. Profit performance: do foreign operations make a difference? Management International Review, 46-56.

6) Fernández, M. and Díez, I. 2015. Internationalization pathways and the performance of SMEs. European Journal of Marketing, Vol. 49 No. 3/4, pp. 420-443.

7) Fowowe, B. 2017. Access to finance and firm performance: Evidence from African countries. Review of development finance, $7(1), 6-17$.

8) Gomes, L. and Ramaswamy, K. 1999. An empirical examination of the form of the relationship between multinationality and performance. Journal of International Business Studies, Vol. 30 No. 1, pp. 173-198.

9) Gomes, L. and Ramaswamy, K. 1999. An empirical examination of the form of the relationship between multinationality and performance. Journal of international business studies, 30(1), 173-187.

10) Héctor Alberto Botello. 2014. Conditions and Determinants of the Internationalization of Latin American Industrial Enterprises. Centro de Investigación de la Universidad del Pacífico, 75(0252-1865), pp. 47-78.

11) Hennart, J. F. 2009. Down with MNE-centric theories! Market entry and expansion as the bundling of MNE and local assets. Journal of International Business Studies, 40(9), 1432-1454.

12) Johanson, J. and Vahlne, J. E. 1977. The internationalization process of the firm-a model of knowledge development and increasing foreign market commitments. Journal of International Business Studies, 8(1), 23-32.

13) Kotabe, M., Srinivasan, S. S. and Aulakh, P. S. 2002. Multinationality and firm performance: The moderating role of R\&D and marketing capabilities. Journal of International Business Studies, 33(1), 79-97.

14) Pratt, C. (Ed.). 1990. Middle power internationalism: The north-south dimension. McGill-Queen's Press-MQUP.

15) Ramasamy, B., Ong, D., and Yeung, M. C. 2005. Firm size, ownership and performance in the Malaysian palm oil industry. Asian Academy of Management Journal of Accounting and Finance, 1, 181-104.

16) Reuber, A. R., and Fischer, E. 1997. The influence of the management team's international experience on the internationalization behaviors of SMEs. Journal of International Business Studies, 28(4), 807-825.

17) Reuer, J. J., Ariño, A., Poppo, L., and Zenger, T. 2016. Alliance governance. Strategic Management Journal, 37(13), E37E44.

18) Ruigrok, W., \& Wagner, H. 2003. Internationalization and performance: An organizational learning perspective. MIR: Management International Review, 63-83.

19) Schwens, C., Zapkay, F.B., Bierweth, M., Bierweth, I., Knight, G. and Kabst, R. 2018. International entrepreneurship: a meta-analysis on the internationalization and performance relationship. Entrepreneurship Theory and Practice, Vol. 45 No. 5, pp. 734-768

20) Sullivan, D. 1994b. The "threshold of internationality": replication, extension, and reinterpretation. Management International Review. 34(2): 165-186

21) Transparency International .2017. Corruption perceptions index. Available at: https://www.transparency.org/en/cpi/2017/index/arg. [accessed 10 February 2021]

22) Tu, P. A., Van Song, N., Van Tien, D., Van Ha, T., Tiep, N. C., Thang, D. Q., and Van Luong, N. 2021. THE MODERATING EFFECTS OF THE MANAGER'S CHARACTERISTICS AND FINANCIAL OBSTACLES ON INTERNATIONALIZATION AND FIRM PERFORMANCE IN POLAND. PalArch's Journal of Archaeology of Egypt/Egyptology, 18(4), 4063-4081.

23) Wang, C. F., Chen, L. Y., \& Chang, S. C. 2011. International diversification and the market value of new product introduction. Journal of International Management, 17(4), 333-347.

24) World Bank data, available at: https://data.worldbank.org/indicator/NV.IND.MANF.ZS?locations=AR. [accessed 10 February 2021]

25) World Bank data, available at: https://data.worldbank.org/indicator/NY.GDP.MKTP.KD.ZG?locations=AR. [accessed 10 February 2021] 